https://helda.helsinki.fi

The significance of supportive and undermining elements in the maternal representations of an unborn baby

\title{
Rusanen, Erja
}

2018-05-03

Rusanen, E , Lahikainen , A , Pölkki , P , Saarenpaa-Heikkila , O \& Paavonen , E J 2018 , ' The significance of supportive and undermining elements in the maternal representations of an unborn baby ', Journal of Reproductive and Infant Psychology , vol. 36 , no. 3 , pp.

261-275 . https://doi.org/10.1080/02646838.2018.1462476

http://hdl.handle.net/10138/301249

https://doi.org/10.1080/02646838.2018.1462476

unspecified

acceptedVersion

Downloaded from Helda, University of Helsinki institutional repository.

This is an electronic reprint of the original article.

This reprint may differ from the original in pagination and typographic detail.

Please cite the original version. 


\section{The significance of supportive and undermining elements in the maternal repre- sentations of an unborn baby}

Rusanen, E. ${ }^{1}$, Lahikainen, A.R ${ }^{2}$., Pölkki, ${ }^{3}{ }^{3}$, Saarenpää-Heikkilä, O. ${ }^{4} \&$ Paavonen, E.J. ${ }^{5,6}$

1. Open University, University of Helsinki, P.O. Box 9 (Siltavuorenpenger 3A), 00014 University of Helsinki, Finland, erja.rusanen@helsinki.fi, tel. +358-50-3790858 (The corresponding author)

2. School of Social Sciences and Humanities, FI-33014, University of Tampere, Finland, Anja.Lahikainen@uta.fi, tel. +358-50-3186140

3. Department of Social Sciences, University of Eastern Finland, Finland, P.O. Box 1627, 70211 Kuopio, Finland, pirjo.polkki@uef.fi, tel. +358-40-355 2647

4. Pediatric Clinics, Tampere University Hospital, P.O. Box 2000, 33521 Tampere, Finland, outi.saarenpaa-heikkila@pshp.fi,tel.+358-3-31167526

5. Department of Health, National Institute for Health and Welfare, Finland, P.O. Box 30, 00271 Helsinki,juulia.paavonen@helsinki.fi,

6. Child Psychiatry, University of Helsinki and Helsinki University Hospital, P.O. Box 400, 00029 HUS, Finland, juulia.paavonen@hus.fi, tel. +358-9-4711. 


\begin{abstract}
Objective. The maternal representations of an unborn baby begin to develop already during pregnancy. However, the factors that moderate them are not well identified. The objective of this study was expressly to jointly explore supportive and undermining factors in the maternal representations of an unborn baby and motherhood.
\end{abstract}

Methods. The article is based on cross-sectional data comprising 1,646 women studied during the third trimester of pregnancy. Maternal expectations were measured using a 12-item self-report questionnaire, Motherô Representations about an Unborn Baby. Depression, anxiety, family atmosphere and adult attachment were measured using standardized questionnaires. Statistical analysis is based on multivariate Linear Regression analysis.

Results. The most powerful predictors of a motherôs prenatal expectations were the motherôs educational status, age, closeness in adult relationships, depressiveness and family atmosphere. In accordance with our hypothesis, depressiveness was related to the motherô more negative expectations on their relationship with the unborn baby and on regularity in the babyô sleeping and eating patterns. A positive family atmosphere and the motherô ability to closeness and dependence (i.e. confidence) in adult relationships were related to more positive expectations of the mother-unborn baby relationship. On the other hand, stress, anxiety and adverse life events were not related to the motherô expectations of her unborn baby.

Conclusions. The results may be helpful in identifying families who need early professional support and call for studies where the prenatal phase is explored as a proactive phase for the development child parent relationship.

Keywords: Prenatal attachment, representation, expectation, pregnancy, motherhood, depression 


\section{Introduction}

A meaningful relationship between a mother and her child begins to develop during pregnancy. Becoming a mother is seen as a transformation process during which a woman anticipates her future role, cognitively prepares herself and practices the tasks which will be needed after the baby has been born (Alhusen, Hayat, \& Gross, 2013).

Different concepts such as maternal-fetal or maternal-infant prenatal attachment (Barone, Lionetti, \& Dellagiulia, 2014; Schwerdtfeger \& Goff, 2007), prenatal expectations (Gress-Smith, Roubinov, Tanaka, Cirnic, Gonzales, Enders \& Luecken, 2013) and maternal prenatal representations (HuthBocks, Theran, Levendosky \& Bogat, 2011) have been used to refer to the motherô expectations, thoughts and emotions about her unborn baby, about motherhood and about pregnancy.

Maternal prenatal representations have been operationalized differently by different authors. For example, Condonôs (1993) prenatal attachment measure with 19 items of the motherô scale focuses on the quality of prenatal attachment (positive, negative, delightful, sad, ambivalent feelings to the fetus) and the quantity of time the parents spend ñin attachment modeò (p. 180). Cranleyôs (1981) Maternal-Fetal Attachment Scale (MFA) with 24 items, comprises emotional and affectional factors related to pregnancy, to future motherhood and to the unborn baby. Mullerô (1993) 21-item questionnaire of Prenatal Attachment Inventory (PAI) had similar elements to Cranley, but the factors were named differently (Barone et al., 2014). Consequently these measures are conceptually overlapping.

In our study, we have explored prenatal expectations concerning mother-child relationship using a 12 item questionnaire (Kangaspunta, Kilkku, Kaltiala-Heino and Punamäki 2005). This study is conducted in the framework of Sternôs (1995) theory. In his view, the concept of representations or ñschemas-of-being-withò refers to the perceived images of self in relation to others. These mental representations, expectations and dreams concerning a baby, called an ñimaginary babyò by Stern 
(1995), are both real and imaginary pictures of interaction with a baby, with a babyô father, with a motherôs parents and with other significant people.

Prenatal representations have been found to evolve during pregnancy due to babyôs movements, which the mother experiences in the weeks after mid-pregnancy (Vedova, Dabrassi \& Imbasciati, 2008; Laxton-Kane \& Slade, 2002; Canella, 2005). Moreover, Vreeswijk, Rijk, Maas and Bakel (2015) found that while representations are stable (from 26 weeks), they become more disengaged before the birth than after it. They assumed (p. 608) that, by avoiding psychologically accession to the baby during pregnancy, the mother protects herself from disappointments that may arise during childbirth.

Previous studies have shown how different psychosocial factors relate to prenatal attachment. Motherô serious trauma-history (Schwerdtfeger \& Goff, 2007), stress (Feldman, 2007; Maas, Vreeswijk, Braeken, Vingerhoets \& van Bakel, 2014; Cranley, 1981), anxiety (Gaffney, 1986) and depression (Rubertsson, Pallant, Sydsjö \& Haines, 2015; Seimyr, Sjögren, Welles-Nyström \& Nissen, 2009) relate to poorer prenatal attachment. On the other hand, there are positive factors, such as social support (Condon \& Corkindale, 1997; Granley, 1981), support from partner or from own parent (Rubertsson, 2015), relationships with significant others (Wayland \& Tate 1993) or attachment to partner or motherô own parents (Bouchard, 2011) that have been related to more positive prenatal representations. However, many findings have been inconsistent or not replicated (Canella, 2004; Laxton-Kane \& Slade, 2002). In addition, studies (such as Bouchard, 2001 and Rubertsson, 2015) where both supportive and risk factors are explored jointly are rare. Our study will contribute to completion of the previous studies in this respect.

In conclusion, in this study we explore how different risk and protective factors (attachment in adult relationships, family atmosphere, anxiety, stress, depression, adverse life events) are associated with the expectations of the mother concerning her unborn child. Based on earlier studies (Walsh, Hepper, Bagge, Wadephul \& Jomeen, 2013), our hypothesis was that lower levels of stress, anxiety, 
depression and adverse life events, more secure attachment scores in adult relationships and a positive family atmosphere jointly relate to more positive prenatal expectations.

\section{Methods}

\section{Sample}

The study is based on the CHILD-SLEEP birth cohort, which is a longitudinal birth cohort to study child sleep quality, its development and health. The cohort was described in detail in Paavonen et al. (2017). Briefly, it is a randomly recruited birth cohort, with data collections during the $32^{\text {nd }}$ week of pregnancy and when the child is 3, 8, 18 and 24 months. Except for language, there were no exclusion criteria. This study is based on cross-sectional data, the maternal reports during pregnancy. The cohort comprises 1,673 families with 1,667 women with returned prenatal questionnaires. A small number of mothers had filled out the questionnaires after the infant was born $(1.2 \%, \mathrm{n}=21)$, and thus this study comprises 1,646 women. The study protocol has been accepted by the local ethical committee (R11032/9.3.2011). All participants gave an informed consent and signed an agreement form. Families were informed of their rights to terminate their participation in the study at any time during data collection.

\section{Questionnaires}

The prenatal questionnaires were given to the mothers at the maternity clinics and included questions on socio-demographic factors, pregnancy and health (e.g. somatic and psychiatric illnesses, height, weight, medication, smoking) as well as standardized questionnaires to evaluate psychiatric symptoms (e.g. depression, anxiety, stress, alcohol usage).

Mothersôexpectations of an unborn baby were measured by a 12-item self-report questionnaire (Representations of Unborn Baby, RUB-M) based on a 5-point Likert scale (ranging from 1 to 5) 
(Kangaspunta et al., 2005). The items are reported in Table 1. In order to determine the latent structure of the scale, maximum likelihood factor analysis was performed. The analyses were first conducted with all 12 variables, and then including only the eight variables with communalities over 0.25 (after extraction). Three factors with Eigenvalues $>1$, explaining $49.61 \%$ of the total variance, were extracted. The first factor was called Positive expectations of the relationship with the baby (Posit-Expt-Relation, $\mathrm{SD}=0.91, \mathrm{n}=1626$ ), the second Negative expectations of taking care of the baby (Negat-Expt-TakingCare, $\mathrm{SD}=0.83, \mathrm{n}=1626$ ), and the third Positive expectations of the babyô regularity (Posit-Expt-Regularity, $\mathrm{SD}=0.75, \mathrm{n}=1626$ ). Factor-scores were used in further statistical analyses. $^{1}$

RUB-M has an affective base as in Condonô (1993) quality part of prenatal attachment measure but with different questions. The items of RUB-M refer both to motherôs expectations about the unborn, future baby and to motherôs expectations of the relationship with the unborn baby and to motherhood. The items of RUB-M are simple and are formulated so that they can be easily understood, which increases the content validity of the measure (Hammond, 1995).

Absence of expectations of the baby (ABS-Expt) were calculated based on the RUB-M original 12item scale (Table 1), recoding option đ́ cannot sayôas 1 and other options as 0 (Kangaspunta et al., 2005). Sums were calculated ( $\alpha=0.73, M=1.84, S D=2.11$, range $0.00-12.00)$. The higher the score, the fewer expectations of the baby that the mother reported.

Mothersôattachment in adult relationships (AAS) was measured by an 18-item self-report questionnaire according to Collins and Reed (1990). There are three subscales that were calculated according to original references (scale 1 ï 5, 1=not true or suitable at all, 5=true), except that one item

\footnotetext{
${ }^{1}$ In addition, in order to confirm the findings, sum-means with original variables were also calculated according to the results of the factor-analysis. The results were the same as with factor-points.
} 
in two sums was excluded in order to improve the reliability of the scale ${ }^{2}$. Example items for Closeness $(\mathrm{M}=4.05, \mathrm{SD}=0.60$, range $1.80-5.00)$ ñ find it relatively easy to get close to othersò, for Dependence, i.e. Confidence $(\mathrm{M}=3.74, \mathrm{SD}=0.78$, range 1.00-5.00) $\tilde{\mathrm{n}}$ am comfortable depending on othersò, for Anxiety $(\mathrm{M}=1.74, \mathrm{SD}=0.70$, range 1.00-4.60) ñ often worry that my partner does not really love meò. Mean-sums were calculated. All subscale scores had good reliability (current data vs. Collins $\&$ Reed (1990): Closeness $\alpha=0.70$ vs. $\alpha=0.69$, Dependence $\alpha=0.86$ vs. $\alpha=0.75$, AASAnxiety $\alpha=0.76$ vs. $\alpha=0.72$ ).

Depressiveness was measured using the 10-item version of the Center for Epidemiological studies Depression Scale, CESD (Radloff, 1977; Irwin, Haydari \& Oxman, 1999). Scale was 0-3, 0=rarely or not at all or less than once a week, 3=all the time or 5-7 days per week. A mean-sum was calculated $(\alpha=0.78, \mathrm{M}=5.11, \mathrm{SD}=3.50$, range $0.00-23.00)$. The higher the sum, the more depressive was the mother.

STAI-Anxiety ${ }^{3}$ was measured using a 6-item shortened version of the Spielberger Trait Anxiety Scale (Bieling, Antony, \& Swinson, 1998). A scale was 1ї 4, 1=almost never, 4= almost always. A mean-sum was calculated $(\alpha=0.78, \mathrm{M}=8.96, \mathrm{SD}=2.38$, range $6.00-21.00)$. The higher the sum the more anxious was the mother.

Stressfulness was measured using the 5-item perceived stress scale by Cohen, Kamarck \& Mermelstein (1983). A scale was 0ї 4, 0=not even once, 4=very often. A mean-sum was calculated $(\alpha=0.69, \mathrm{M}=5.69, \mathrm{SD}=2.89$, range 0.00-18.00). The higher the sum, the more stressed was the mother.

\footnotetext{
${ }^{2}$ AAS-Anxiety with 5 items excluded variable ñI want to merge completely with another personò, Closeness with 5 and ClosenessDependence with 11 items, excluded variable ñI am comfortable having others depend on meò.

${ }^{3}$ The variable is called STAI-Anxiety in the text in order to distinguish the concept from AAS-Anxiety in adult relationships, measured by the Adult Attachment Scale (AAS).
} 
Adverse life events during the last 6 months were measured using the Life Events Scale (LTE), which lists 11 potentially distressing life events (Brugha \& Cragg, 1990). A scale was 1ï 2, 1=yes, 2=no. Dummy variables were recorded (no distressing events=0). A mean-sum was calculated $(\alpha=0.53, M=0.64, S D=1.05$, range $0.00-11.00)$. The higher the sum, the greater the number of adverse life events a mother has had.

Family atmosphere was evaluated using a 7-item Likertï type scale (1ї 7). Example items ñexciteï chattyò, ñsafeï insecureò (reversed scale). A mean-sum was calculated $(\alpha=0.86, M=42.52, \mathrm{SD}=5.24$, range 14.00-49.00). The higher the sum, the better was the familyatmosphere.

Educational status from lowest to highest (1ї4), based on the length and grade of the motherôs education, was created by combining the variables of q́rofessional educationôand óasic educationô into a new variable. (Table 2)

\section{Statistical analyses}

Frequency analysis was performed first. Thereafter, Spearman correlation coefficients were calculated between the independent (i.e.explanatory) and the dependent variables (Table 3). Finally, linear regression analysis was performed (Table 4). Models were created to study factors that are related to the dependent variables. The main explanatory variables were defined according to previous literature, comprising both risk factors (stress, STAI-Anxiety, depression and adverse life events), supportive factors (family atmosphere and motherôs security in adult relationships) and the background variables (the motherôs educational status, age, number of pregnancies, gestational age and income). All these variables were included in the same linear regression model so as to evaluate their relative contribution to the outcome variable. According to the tests, there was no multicollinearity in the data $(0.1<$ Tolerance $<1$ and VIF $<10)$. 


\section{Results}

\section{Description of the sample}

The socio-demographic factors of the sample are reported in Table 2. Concerning mothersôage (Vuori \& Gissler, 2014) and income (OSF, 2013) they are similar to the general data of Finnish pregnant women but mothers in our sample are higher educated (OSF, 2016).

\section{Correlation analyses}

The results of the correlation analysis are presented in Table 3. Of the main explanatory variables, we found that the greater closeness-dependence (i.e. security) in adult relationships (also with the partner) and the better family atmosphere were related to the more positive expectations of the relationship with the baby $(\mathrm{p}<0.001)$ and less negative expectations of taking care of the baby $(\mathrm{p}<0.001)$. Stress, anxiety (measured by STAI) and depression were related to more negative expectations of taking care of the baby $(\mathrm{p}<0.001)$ and to fewer $(\mathrm{p}<0.01)$ expectations of the baby. In addition, the more depressed the mother was, the less she expected the babyô regularity $(\mathrm{p}<0.001)$.

Regarding background variables, the motherô higher education was related to less positive expectations of the relationship with the baby $(\mathrm{p}<0.001)$ and to more negative expectations of taking care of the baby $(\mathrm{p}<0.01)$. Younger age was related to the more positive expectations of relationship with the baby $(\mathrm{p}<0.001)$, more negative expectations of taking care of the baby $(\mathrm{p}<0.001)$ and fewer expectations of the baby $(\mathrm{p}<0.001)$. (Table 3$)$

\section{Regression analysis}

Linear regression analyses were conducted in order to study factors that are related to the motherôs expectations in the end of a pregnancy. In these models, lower level of depressiveness was related to positive expectations of the relationship with the baby $(\beta=-0.120, p=0.003)$. Moreover, motherô relationships were related to positive expectations: closeness in adult relationships $(\beta=0.152$, 
$\mathrm{p}<0.001)$, positive family atmosphere $(\beta=0.095, \mathrm{p}=0.003)$ and the motherô dependence i.e. confidence in adult relationship $(\beta=0.075, \mathrm{p}=0.04)$ were related to more positive expectations. Anxiety in adult relationship (measured by AAS) was related to positive expectations of her relationship with her baby $(\beta=0.072, p=0.043)$. Of the background factors higher education (university education, $\beta=-$ 0.172, $\mathrm{p}<0.001$ and polytechnic education, $\beta=-0.102, \mathrm{p}<0.001$ ), and intermediate income were associated with less positive expectations $(\beta=-0.059, \mathrm{p}=0.044)$. (Table 4$)$.

Negative expectations of taking care of the baby. Of the main explanatory variables, only more negative family atmosphere $(\beta=-0.090, p=0.007)$, and the motherôs weaker closeness in adult relationships $(\beta=-0.080, p=0.015)$, were related to more negative expectations of taking care of the baby. The strongest variables explaining negative expectations taking care of the baby were the motherô university education $(\beta=0.124, \mathrm{p}=0.004)$ and younger age $(\beta=-0.116, \mathrm{p}<0.001)$. Finally, the first pregnancy and pregnancy exceeding 32 weeks were related positively $(\beta=0.060, p=0.0345$; $\beta=0.064, p=0.017$, respectively) to negative expectations of taking care of the baby. (Table 4 ).

Positive expectations of the babyô regularity in eating and sleeping. A motherô depressiveness $(\beta=-0.177, \mathrm{p}<0.001)$ and higher education (university education: $\beta=-0.098, \mathrm{p}=0.026)$ were associated with a motherôs more negative expectations of her babyố regularity in sleeping and eating. (Table 4).

Expectations of the baby were more often absent when the mother reported less closeness in adult relationships $(\beta=-0.092, p=0.006)$. They were also related to younger age $(\beta=-0.065, p=0.034)$, first pregnancy $(\beta=0.060, p=0.038)$ as well as a later stage of the pregnancy (i.e. exceeding 32 weeks) $(\beta=0.076, p=0.006)$. (Table 4). 


\section{Discussion}

Our aim was to jointly explore the supportive and risk factors for maternal representations of an unborn baby at the end of a pregnancy. While prenatal attachment mostly refers to the thoughts about the fetus, our measure refers to the motherôs thoughts and feelings regarding the future baby. Based on earlier studies, we assumed that lower levels of different environmental risk factors jointly with higher levels of supportive factors are positively related to the motherôs expectations of her unborn baby and of motherhood.

We found that depressiveness was one of the strongest risk factors, being related to the mother's negative expectations. The more depressive the mother was, the less she had positive expectations of the relationship with her baby and the less she expected regularity from the baby (i.e. less predictability concerning eating and sleeping). Our results support the findings by Rubertsson et al. (2015), according to which more depressive mothers had lower prenatal attachment scores. Also according to Seimyr et al. (2009) depressive mothers have more negative attitudes to their pregnancy and their body which, as we suppose, can also increase negative expectations concerning the future baby.

However, contrary to our assumptions, the other risk elements of mental health disorders (stress, STAI-Anxiety, adverse life events) were not related to maternal representations. Our results partly supported the findings of Schwerdtfeger and Goff (2007), according to which motherô total trauma-history (including serious and numerous traumas similar to those in our study, including unemployment and death of family members or friends) did not predict prenatal attachment, but that an inter-personal trauma history was a negative predictor.

Regarding perceived stress, our finding is partly in agreement with previous studies, because stress was not related to a motherô expectations of her baby, of the relationship or of motherhood. Our findings support Siddiqui and Hägglöfôs (1999) results, according to which psychosomatic symptoms (including overall distress) do not relate to prenatal attachment. It has also been reported that 
less stress on the part of the mother during pregnancy predicts a more positive prenatal attachment (Feldman, 2007; Maas et al., 2014). On the other hand, the pregnant womanôs depression, stress and anxiety are often combined (Latva \& Moilanen, 2016). Positive correlations between stress, depression and STAI-anxiety were also evidenced in our study $(\mathrm{r}=0.59-0.61, \mathrm{p}<0.001)$.

Motherô positive expectations were supported by a positive family atmosphere, the motherô capacity for closeness and dependency in adult relationships, including a spouse. In this context, our results support the findings by Rubertsson et al. (2015), which showed that lack of a partnerôs support is connected to lower prenatal attachment scores (in terms of PAI-R ${ }^{4}$ ).

Closeness and dependence i.e. confidence in adult relationships were associated with positive expectations, and closeness was also inversely associated with negative expectations of taking care of the baby. In addition, the more closeness mother had in her adult relationships, the more representations of an unborn baby and of motherhood she generated. These findings corresponded with the results of Maas et al. (2014), according to which a secure attachment in adult relationships provides better conditions for mothers to develop an emotional relationship with their unborn baby.

Good family atmosphere related to positive expectations of the relationship with the baby and to less negative expectations of taking care of the baby. Previous studies indicate that the support of the spouse is positively related to the motherô ability to create a better emotional relationship with her unborn baby. For example, social support for the mother (Huth-Bocks et al., 2011; Laxton-Kane \& Slade, 2002) protects the emotional bond between mother and child both before and after birth. Moreover, Feldman (2007) reported that the teenage mother's expectations of support by those close to her with a baby increased prenatal attachment. Similarly Huth-Bocks, Levendosky, Theran and Bogat (2004) reported that domestic violence (i.e. conflicts in marital relations) related to more

\footnotetext{
${ }^{4}$ Prenatal Attachment Inventory - Revised (Rubertsson et al., 2015).
} 
negative representations of an unborn baby, which can transmitted in the form of an insecure attachment after birth (Huth-Bocks et al., 2011).

Concerning mothersôeducation, higher education was related to more negative expectations, but not absence of expectations of the baby. Mothers with a university or polytechnic degree had less positive expectations of relationship with the baby, and mothers with a university degree had more negative expectations of taking care of the baby and expected less regularity (i.e. predictability ${ }^{5}$ ) in their babyôs sleeping and eating compared to the mothers with the lowest education. Previous findings have been contradictory according to an integrative study by Canella (2004). In the study by Barone et al. (2014) it appeared that the motherôs education did not relate to her emotional bond with the unborn baby (i.e. prenatal attachment). In our study, the motherôs education is one of the most powerful explanatory factors. This is in harmony with findings by Rubertsson et al. (2015) concerning Swedish mothers with university or college education who had lower prenatal attachment scores than mothers with elementary or high school education. The results of education could be explained by a stronger role-conflict between family-life and work. A role-conflict can be stronger by highly educated mothers, because in Finland their working weeks are longer ${ }^{6}$ and more stressful than those of mothers with a shorter education (see Gallie \& Russell, 2009; Matthews, Swody \& Barnes-Farrell, 2012; Palmer, Rose, Sanders \& Randle, 2012). Highly educated mothers might be aware that both work and baby need more time than is available.

Mothers whose pregnancy had proceeded beyond 32 weeks had more negative expectations of taking care of their baby and generally less expectations compared to mothers with a pregnancy of

\footnotetext{
${ }^{5}$ Our interpretation of higher regularity as a positive factor is relevant based on the findings by Maas et al. (2014) and Zeanahô, Carrôs and Wolkôs (1990) findings concerning positive association between predictability and mother-fetal-attachment.

${ }^{6}$ Lower employees worked less than 35 hours per week more often than higher in Finland in 2014 (OSF, 2014).
} 
less than 32 weeks. This might be because, as Stern (1995) assumed, a woman protects herself against possible disappointments caused by the real baby.

The age of mothers related inversely to negative and absence of expectations. Younger mothers had more negative expectations of taking care of their baby, and they also had less expectations of the baby. Previous results vary concerning association between age and prenatal relationship. Siddiqui and Hägglöf (1999) and Lindgren (2001) found, contradictory to our results, that younger mothers had stronger attachment to their unborn baby compared to older mothers. According to Canella (2004), most studies have not found this kind of correlation. Nor did the findings by Barone et al. (2014) show differences between younger and older womenôs prenatal attachment. In the longitudinal sample, we will further study whether younger women are at a greater risk of creating a weaker emotional bond with their baby after birth.

\section{Limitations}

A few limitations of the findings must be noted. Firstly, although we were able to show several factors that are related to maternal expectations of an unborn baby, they explained the variance in the data only to small extent, and thus further studies are needed to fully understand the formulation of motherôs expectations of an unborn baby. Secondly, we must also be cautious in our interpretation of our measure of maternal expectations (RUB-M), because it is different to other measures that have been used previously. Concerning the subject of prenatal attachment, there are several studies made in different countries but with varying measures. This reduces the comparability of different studies. For this reason, we suggest in the future studies to compare different scales which have been developed to measure prenatal attachment, representations, expectations and affectional bond to an unborn baby for evaluating predictive validity. 
In this study, we have assessed the motherôs expectations as if they were permanent factors, although according to Raphael-Leffôs (2010) theory (of a healthy ambivalence) a pregnant woman's feelings can fluctuate significantly from negative to positive and vice versa. In further studies, it will be important to examine whether a single evaluation (once during pregnancy) could predict how the relationship between a mother and a baby might develop after birth.

\section{Conclusions}

Summarizing our results, motherô lower depressiveness and good relationships inside and outside the family (i.e. good family atmosphere, security) were the most important predictors of motherô positive expectations concerning the baby. On the other hand, motherôs higher education, motherôs younger age, pregnancy over 32 weeks and first pregnancy predicted more negative expectations. The results may be helpful in identifying families who need early professional support. As part of a longitudinal study, which contains data from the prenatal to postnatal phase, we are going to analyse how a motherô prenatal representations predict the development of the relationships between mother and child, and how they, together with the background factors, predict a childô socioemotional development. 


\section{References}

Alhusen, J. L., Hayat, M. J., \& Gross, D. (2013). A longitudinal study of maternal attachment and infant developmental outcomes. Archives of Womenôs Mental Health, 16(6), 521 ï 529. https://doi.org/10.1007/s00737-013-0357-8

Barone, L., Lionetti, F., \& Dellagiulia, A. (2014). Maternal-fetal attachment and its correlates in a sample of Italian women: A study using the Prenatal Attachment Inventory. Journal of Reproductive and Infant Psychology, 32(3), 230ї 239. http://doi.org/10.1080/02646838.2014.883596

Bieling, P. J., Antony, M. M., \& Swinson, R. P. (1998). The state-trait anxiety inventory, trait version: Structure and content re-examined. Behaviour Research and Therapy, 36(7ї 8), 777 ï 788. http://doi.org/10.1016/S0005-7967(98)00023-0

Bouchard, G. (2011). The role of psychosocial variables in prenatal attachment: an examination of moderational effects. Journal of Reproductive and Infant Psychology, 29, $197 i$ 207. http://doi.org/10.1080/02646838.2011.592975

Brugha, T. S., Cragg, D. (1990). The List of Threatening Experiences: the reliability and validity of a brief life events questionnaire. Acta psychiatric Scand., 82 (1), 77-81.

Canella, B. L. (2004). Maternal-fetal attachment: an integrative review. Journal of Advanced Nursing, 50 (1), 60-68.

Cohen, S., Kamarck, T. \& Mermelstein, R. (1983). A global measure of perceived stress. Journal of Health and Social Behavior, 24, 385ï 396. http://doi.org/10.2307/2136404

Collins, N. L., \& Reed, S. J. (1990). Adult attachment, working models, and relationship quality in dating couples. Journal of Personality and Social Psychology, 58 (4), 644 ï 663. http://doi.org/10.1037/0022-3514.58.4.644

Condon, J. T. (1993). The assessment of antenatal emotional attachment: Development of a questionnaire instrument. British Journal of Medical Psychology, 66, 167-183.

Condon, J.T. \& Corkindale, C. (1997). The correlates of antenatal attachment in pregnant wome. British Journal of Medical Psychology, 70, 359-372.

Cranley, M. S. (1981). Development of a Tool for the Measurement of Maternal Attachment During Pregnancy. Nursing Research, 30 (5), 281-284.

Feldman, J. B. (2007). The effect of support expectations on prenatal attachment: An evidencebased approach for intervention in an adolescent population. Child and Adolescent Social Work Journal, 24 (3), 209ï 234. http://doi.org/10.1007/s10560-007-0082-0

Field, A. (2013). Discovering statistics using IBM SPSS statistics. London. SAGE.

Gaffney, K., F. (1986). Maternal-fetal attachment in relation to self-concept and anxiety. MaternalChild Nursing Journal, 15 (2), 91-101.

Gallie, D., Russell, H. (2009). Work - Family Conflict and Working Conditions in Western Europe. Social Indicators Research, 93 (3), 445-467.

Gress-Smith, J. L., Roubinov, D. S., Tanaka, R., Cirnic, K., Gonzales, N., Enders, C., \& Luecken, L. J. (2013). Prenatal expectations in Mexican American women: Development of a culturally sensitive measure. Archives of Womenô Mental Health, 16 (4), 303 ï 314. http://doi.org/10.1007/s00737-013-0350-2 
Hammond, S. (1995). Using Psychometric Tests. Research methods in psychology, eds. Breakwell, G. M., Hammond, S., Fife-Schaw, C. London: SAGE Publications.

Huth-Bocks, A. C., Levendosky, A. A., Theran, S. A., \& Bogat, G. A. (2004). The impact of domestic violence on mothers ôprenatal representations of their infants, Infant mental health journal, 25 (2), 79ï 98. https://doi.org/10.1002/imhj.10094

Huth-Bocks, A. C., Theran, S. A., Levendosky, A. A., Bogat, G. A. (2011). A Social-contextual understanding of concordance and discordance between maternal prenatal representations of the infant and infant $\ddot{i}$ mother attachment, Infant mental health journal, 32(4), $405 \ddot{I} 426$. http://doi.org/10.1002/imhj.

Irwin, M., Haydari, K., \& Oxman, M. (1999). Screening for Depression in the Older Adult. Archives of International Medicine, 159, 10ї 13. http://doi.org/10.1001/archinte.159.15.1701.

Kangaspunta, R., Kilkku, N., Kaltiala-Heino, R., \& Punamäki, R-L. (2005). Lapsiperheiden psykososiaalinen tukeminen. Pirkanmaan mielenterveystyön hankkeen peruspalvelutiimi- ja perheen hyvinvointineuvola ï projektin loppuraportti 2002-2004. [Psycho-social support for families. Pirkanmaa mental health project regarding child wellfare clinics, final report 2002-2004].

Latva, R., Moilanen, I. (2016). Prenataaliset riskitekijät. Translation Prenatal risk factors. Childand youth-psychiatry. Ed. by A. Sourander. Duodecim: Helsinki, 71-74.

Laxton-Kane, M. \& Slade, P. (2002). The role of maternal prenatal attachment in a womanôs experience of pregnancy and implications for the process of care. Journal of Reproductive and Infant Psychology, 20(4), 253ï 266. http://doi.org/10.1080/0264683021000033174

Lindgren, K. (2001). Relationships Among Maternal - Fetal Attachment, Prenatal Depression , and Health Practices in Pregnancy. Research in Nursing \& Health, 2001, 24, 203-217

Maas, J. B. M., Vreeswijk, C. M. J. M., Braeken, J., Vingerhoets, A. J. J. M. \& van Bakel, H. J. (2014). Determinants of maternal fetal attachment in women from a community-based sample. Journal of Reproductive \& Infant Psychology, 32(1), 5 ï 24. http://doi.org/10.1080/02646838.2013.853170

Matthews, R. A., Swody, C. A., \& Barnes-Farrell, J. L. (2012). Work Hours and Work Ï Family Conflict [l:The Double-edged Sword of Involvement in Work and Family, 247, 234 ï 247. https://doi.org/10.1002/smi.1431

Menard, S. (1995). Applied logistic regression analysis. In Field, A. (2013). Discovering statistics using IBM SPSS statistics. London: SAGE.

Muller, M.,E. (1993). Development of the Prenatal Attachment Inventory. Western Journal of Nursing Research, 15 (2), 199-211. DOI: 10.1177/019394599301500205

Myers, R. (1990). Classical and modern regression with applications (2 ${ }^{\text {nd }}$ ed.).Boston, MA:

Duxbury.

OSF, Official Statistics of Finland. (2013). Tulonjakotilasto (Statistics of income distribution). Statistics Finland.

OSF, Official Statistics of Finland. (2014). Working hours in 2014. Statistics Finland.

http://tilastokeskus.fi/til/tyti/2014/13/tyti_2014_13_2015-04-28_kat_003_fi.html, read on the 2:th of Feb. 2017. 
OSF, Official Statistics of Finland. (2016). Kansallinen koulutusaste (National level of education). Statistics Finland.

Paavonen, E.J., Saarenpää-Heikkilä, O, Pölkki, P, Kylliäinen, A., Porkka-Heiskanen, T., Paunio, T. (2016). Maternal and paternal sleep during pregnancy in the Child-Sleep birth cohort. Submitted on the 24:th of August 2016.

Palmer, M; Rose, D., Sanders, M., Randle, F. (2012). Conflict between work and family among New Zealand teachers with dependent children. Teaching and Teacher Education, 28 (7), 1049 Ï 1058.

Radloff, L..S. (1977). The CES-D scale: A self report depression scale for research in the general population. Applied Psychological Measurement, 1 (3), 385-401.

Raphael-Leff, J. (2010). Healthy Maternal Ambivalence. Psycho-analytic Psychotherapy in South Africa, 18 (2), 57-73.

Rubertsson, C., Pallant, J.F., Sydsjö, G., Haines, H.M. \& Hildingsson, I. (2015). Maternal depressive symptoms have a negative impact on prenatal attachment - findings from a Swedish community sample. Journal of Reproductive and Infant Psychology, 33 (2), 153-164. https://doi.org/10.1080/02646838.2014.992009

Schwerdtfeger, K. L., \& Goff, B. S. N. (2007). Intergenerational Transmission of TraumaltExploring Mother Ï Infant Prenatal Attachment, 20(1), 39ï 51. http://doi.org/10.1002/jts.

Seimyr, L., Sjögren, B., Welles-Nyström, B. \& Nissen, E. (2009). Antenatal maternal depressive mood and parental-fetal attachment at the end of pregnancy. Arch Womens Mental Health, 12, 269279. DOI 10.1007/s00737-009-0079-0

Siddiqui, A., Hägglöf, B. (1999). An exploration of prenatal attachment in Swedish expectant women. Journal of reproductive and infant psychology, 17 ( 4 ), $368 і ̈ 380$.

Stern, D. (1995). Motherhood Constellation: A Unified View of Parent-Infant Psychotherapy. London, GBR: Karnac Books.

Vedova, A. M. Della, Dabrassi, F. \& Imbasciati, A. (2008). Assessing prenatal attachment in a sample of Italian women. Journal of Reproductive and Infant Psychology, 26 (2), $86 і ̈ 98$. http://doi.org/10.1080/02646830701805349

Vreeswijk, C., Rijk, C., Maas, J., \& Rakel, H. (2015). Fathersôand mothersôrepresentations of the infant: Associations with prenatal risk factors. Infant mental health journal, 36 (6), 599-612. DOI: 10.1002/imhj.21541

Vuori, E. \& Gissler, M. (2014). Perinataalitilasto ï synnyttäjät, synnytykset ja vastasyntyneet 2014. Perinatalstatistik ï föderskor, förlossningar och nyfödda 2014. Perinatal statistics: parturients, deliveries and newbornes. National Institute for Health and Welfare, 19, 2015.

Walsh, J., Hepper, E. G., Bagge, S. R., Wadephul, F., \& Jomeen, J. (2013). Maternalï fetal relationships and psychological health: emerging research directions. Journal of Reproductive \& Infant Psychology, 31(5), 490ї 499. http://doi.org/10.1080/02646838.2013.834311

Wayland J, Tate S. (1993). Maternal-fetal attachment and perceived relationships with important others in adolescents. Birth, 20(4), 198-203. 
Zeanah, C. H., Carr, S., \& Wolk, S. (1990). Fetal movements and the imagined baby of pregnancy: Are they related? Journal of Reproductive and Infant Psychology, 8(1), 23 ï 36.

https://doi.org/10.1080/02646839008403605 
Table 1. Distribution of original variables of maternal expectations and the factor loadings of the final factor solution.

\begin{tabular}{|c|c|c|c|c|c|c|c|c|c|c|c|c|c|}
\hline \multirow{2}{*}{$\begin{array}{l}\text { I imagine that my } \\
\text { babyé }\end{array}$} & \multicolumn{2}{|c|}{ Not at all } & \multicolumn{2}{|c|}{ Somewhat } & \multicolumn{2}{|c|}{$\begin{array}{l}\text { Cannot } \\
\text { say }\end{array}$} & \multicolumn{2}{|c|}{ Much } & \multicolumn{2}{|c|}{ Very much } & \multirow{2}{*}{$\begin{array}{l}\text { Posit- } \\
\text { Expt- } \\
\text { Relation }\end{array}$} & \multirow{2}{*}{$\begin{array}{l}\text { Negat- } \\
\text { Expt- } \\
\text { Taking- } \\
\text { Care }\end{array}$} & \multirow{2}{*}{$\begin{array}{l}\text { Posit-Expt- } \\
\text { Regularity }\end{array}$} \\
\hline & f & $\%$ & $\mathbf{f}$ & $\%$ & f & $\%$ & $\mathbf{f}$ & $\%$ & f & $\%$ & & & \\
\hline will sleep regularly & 92 & 5.6 & 809 & 49.1 & 302 & 18.3 & 388 & 23.6 & 48 & 2.9 & 0.013 & -0.238 & 0.614 \\
\hline $\begin{array}{l}\text { will be difficult to } \\
\text { breast-feed }\end{array}$ & 600 & 36.5 & 549 & 33.4 & 429 & 26.1 & 55 & 3.3 & 10 & 0.6 & -- & -- & -- \\
\hline $\begin{array}{l}\text { will follow a pre- } \\
\text { cise eating rhythm }\end{array}$ & 179 & 10.9 & 769 & 46.7 & 423 & 25.7 & 257 & 15.6 & 12 & 0.7 & 0.042 & 0.024 & 0.580 \\
\hline $\begin{array}{l}\text { will be satisfied and } \\
\text { happy }\end{array}$ & 7 & 0.4 & 161 & 9.8 & 147 & 8.9 & 949 & 57.5 & 374 & 22.7 & 0.290 & -0.390 & 0.367 \\
\hline $\begin{array}{l}\text { will seem unfamil- } \\
\text { iar and strange }\end{array}$ & 1349 & 82.0 & 161 & 9.8 & 124 & 7.5 & 6 & 0.4 & 1 & 0.1 & -- & -- & -- \\
\hline will enjoy himself & 232 & 14.1 & 960 & 58.3 & 360 & 21.9 & 81 & 4.9 & 9 & 0.5 & -- & -- & -- \\
\hline $\begin{array}{l}\text { will calm down } \\
\text { easily on my lap }\end{array}$ & 13 & 0.8 & 166 & 10.1 & 127 & 7.7 & 974 & 59.2 & 361 & 21.9 & 0.317 & -0.465 & 0.265 \\
\hline $\begin{array}{l}\text { will not be easy to } \\
\text { calm down }\end{array}$ & 453 & 27.5 & 763 & 46.4 & 395 & 24.0 & 26 & 1.6 & 5 & 0.3 & -0.078 & 0.720 & -0.056 \\
\hline $\begin{array}{l}\text { will wake up con- } \\
\text { tinuously at night }\end{array}$ & 123 & 7.5 & 937 & 56.9 & 309 & 18.8 & 220 & 13.4 & 50 & 3.0 & -- & -- & -- \\
\hline $\begin{array}{l}\text { will suffer and be } \\
\text { restless }\end{array}$ & 760 & 46.2 & 499 & 30.3 & 361 & 21.9 & 17 & 1.0 & 4 & 0.2 & -0.091 & 0.671 & -0.069 \\
\hline $\begin{array}{l}\text { will be adorably } \\
\text { cute }\end{array}$ & 1 & 0.1 & 14 & 0.9 & 28 & 1.7 & 361 & 21.9 & 1238 & 75.2 & 0.851 & -0.130 & 0.033 \\
\hline $\begin{array}{l}\text { will cause me great } \\
\text { joy }\end{array}$ & 1 & 0.1 & 14 & 0.9 & 20 & 1.2 & 281 & 17.1 & 1326 & 80.6 & 0.825 & -0.144 & 0.066 \\
\hline
\end{tabular}

Nôs ranged from 1638-1643 
Table 2. Description of the sample

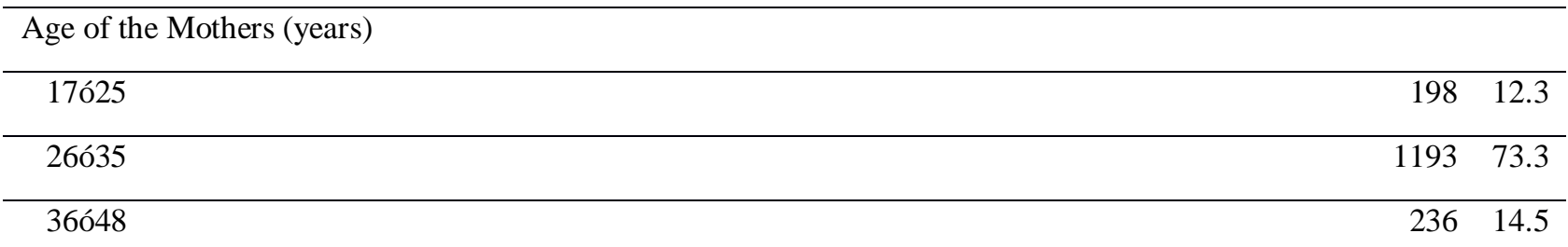

Gestational age of the Mothers (weeks)

32 or less

Order of pregnancy

First
Second
Third
Fourth or more

Disposable income of the Mothers (euros)

\begin{tabular}{|c|c|c|}
\hline Less than 1,000 & 371 & 23.2 \\
\hline $1,000 \ddot{1} 2,000$ & 816 & 50.7 \\
\hline $2,000 \ddot{I} 3000$ & 357 & 22.2 \\
\hline $3,000 \ddot{1} 4,000$ & 51 & 3.2 \\
\hline More than 4,000 & 13 & 0.8 \\
\hline \multicolumn{3}{|l|}{ Vocational degrees } \\
\hline University (highest level) & 550 & 33.4 \\
\hline Applied sciences (upper secondary level) & 597 & 36.3 \\
\hline Secondary level (lower secondary level) & 343 & 20.9 \\
\hline Vocational course(s) & 22 & 1.3 \\
\hline No vocational education & 96 & 5.8 \\
\hline Something else & 37 & 2.2 \\
\hline \multicolumn{3}{|l|}{ Educational status (basic and vocational education) } \\
\hline 1.Comprehensive school + vocational education at a lower secondary level (maximum) & 278 & 17.3 \\
\hline $\begin{array}{l}\text { 2.Comprehensive school + vocational education at an upper secondary level or degree from a universi- } \\
\text { ty of applied sciences or high-school diploma + vocational education at a lower secondary level }\end{array}$ & 303 & 18.9 \\
\hline $\begin{array}{l}\text { 3.High-school diploma + vocational education at an upper secondary level or degree from a university } \\
\text { of applied sciences }\end{array}$ & 476 & 29.6 \\
\hline 4.Comprehensive school or High-school diploma + graduated from a science university & 550 & 34.2 \\
\hline
\end{tabular}

Nô ranged from 1607-1645. 
Table 3. Spearman correlations of mothersômental health attenuating variables (Stress, STAI-Anxiety, Depressiveness, Adverse life events), supporting variables (family atmosphere, attachment of mothers) and background variables with Motherô Representations of an Unborn Baby.

Variable

(Number of items)

ABS-EXPT

\begin{abstract}
POSIT
\end{abstract}
EXPT

RELATION
NEGAT-

EXPT-

TAKING-

CARE
POSIT

EXPT-

REGULARITY

\begin{tabular}{|c|c|c|c|c|}
\hline & $\mathrm{r}$ & $\mathrm{r}$ & $\mathrm{r}$ & $\mathrm{r}$ \\
\hline Closeness* & $-0.14 * * *$ & $0.13 * * *$ & $-0.16 * * *$ & $0.02 \mathrm{~ns}$ \\
\hline Dependence (i.e. confidence) & $-0.13 * * *$ & $0.10 * * *$ & $-0.15 * * *$ & $0.02 \mathrm{~ns}$ \\
\hline AAS-Anxiety** & $0.05^{*}$ & $-0.09 * * *$ & $0.09 * * *$ & $0.00 \mathrm{~ns}$ \\
\hline Closeness-Dependence**** & $-0.15 * * *$ & $0.12 * * *$ & $-0.18 * * *$ & $0.02 \mathrm{~ns}$ \\
\hline Family atmosphere & $-0.04 \mathrm{~ns}$ & $0.16 * * *$ & $-0.16 * * *$ & $0.04 \mathrm{~ns}$ \\
\hline Adverse life events & $0.06 * *$ & $0.02 \mathrm{~ns}$ & $0.01 \mathrm{~ns}$ & $0.03 \mathrm{~ns}$ \\
\hline Stress & $0.07 * *$ & $-0.06 *$ & $0.13 * * *$ & $-0.05^{*}$ \\
\hline STAI-Anxiety & $0.07 * *$ & $-0.07 * *$ & $0.15 * * *$ & $-0.05+$ \\
\hline Depressiveness & $0.07 * *$ & $-0.04+$ & $0.10 * * *$ & $-0.09 * * *$ \\
\hline Monthly income & $-0.01 \mathrm{~ns}$ & $-0.2 \mathrm{~ns}$ & $0.06 *$ & $0.01 \mathrm{~ns}$ \\
\hline Educational status & $-0.00 \mathrm{~ns}$ & $-0.10 * * *$ & $0.07 * *$ & $0.04 \mathrm{~ns}$ \\
\hline Motherô age & $-0.10 * * *$ & $-0.09 * * *$ & $-0.10 * * *$ & $-0.02 \mathrm{~ns}$ \\
\hline
\end{tabular}

$* \mathrm{p}<0.05, * * \mathrm{p}<0.01, * * * \mathrm{p}<0.001,+0.05$ Oेp<0.10, Nôs ranged from 1589-1624

Closeness*: with excluded item ñI am comfortable having others depend on meò.

Anxiety**: with excluded item ñI want to merge completely with another personò.

Closeness-Dependence***: with excluded item I am comfortable having others depend on meò. 
Table 4. Results of the multiple regression analysis for maternal representations about the unborn baby concerning $1 \mathrm{i} 4$ models.

\begin{tabular}{|c|c|c|c|c|c|}
\hline $\begin{array}{l}\text { Model 1. Positive Expectations of the rel } \\
\text { the baby }\end{array}$ & & & & & \\
\hline Explanatory variables & B & SE B & b & $\mathbf{t}$ & $\mathbf{p}$ \\
\hline Adverse life events & 0.034 & 0.025 & 0.037 & 1.366 & ns. \\
\hline Depressiveness & -0.031 & 0.011 & -0.120 & -2.959 & 0.003 \\
\hline STAI- Anxiety & 0.013 & 0.016 & 0.032 & 0.797 & ns. \\
\hline Stress & -0.010 & 0.013 & -0.030 & -0.760 & ns. \\
\hline Family atmosphere & 0.017 & 0.006 & 0.095 & 2.929 & 0.003 \\
\hline Closeness* & 0.234 & 0.050 & 0.152 & 4.680 & $<0.001$ \\
\hline Dependence (i.e. confidence) & 0.088 & 0.043 & 0.075 & 2.058 & 0.040 \\
\hline AAS- Anxiety** & 0.096 & 0.047 & 0.072 & 2.026 & 0.043 \\
\hline Educational status (alternative $2=1$ ) $* * *$ & -0.123 & 0.083 & -0.051 & -1.473 & ns. \\
\hline Educational status (alternative $3=1$ ) $* * *$ & -0.205 & 0.077 & -0.102 & -2.652 & 0.008 \\
\hline Educational status (alternative $4=1$ ) ${ }^{* * *}$ & -0.329 & 0.081 & -.172 & -4.068 & $<0.001$ \\
\hline Maternal age & -0.002 & 0.006 & -0.009 & -0.300 & ns. \\
\hline Number of pregnancy $($ first $=1$ ) & -0.072 & 0.052 & -0.038 & -1.379 & ns. \\
\hline Gestational age ( $>32$ weeks $=1$ ) & 0.004 & 0.066 & 0.002 & 0.065 & ns \\
\hline Maternal income $(>3,000 u ́=1)$ & 0.076 & 0.122 & 0.017 & 0.621 & ns. \\
\hline Maternal income $(2,000 і ̈$ 3,000ú=1) & -0.129 & 0.064 & -0.059 & -2.019 & 0.044 \\
\hline $\begin{array}{l}\text { Model 2. Negative expectations of taking } \\
\text { baby }\end{array}$ & & & & & \\
\hline Adverse life events & -0.028 & 0.023 & -0.033 & -1.224 & ns. \\
\hline Depressiveness & -0.002 & 0.010 & -0.009 & -0.225 & ns. \\
\hline STAI-Anxiety & 0.026 & 0.015 & 0.074 & 1.823 & 0.068 \\
\hline Stress & 0.016 & 0.012 & 0.056 & 1.380 & ns. \\
\hline Family atmosphere & -0.014 & 0.005 & -0.090 & -2.719 & 0.007 \\
\hline Closeness* & -0.112 & 0.046 & -0.080 & -2.429 & 0.015 \\
\hline Dependence (i.e. confidence) & -0.046 & 0.039 & -0.043 & -1.157 & ns. \\
\hline AAS-Anxiety** & -0.036 & 0.044 & -0.030 & -0.832 & ns. \\
\hline Educational status (alternative $2=1$ ) $* * *$ & 0.057 & 0.077 & 0.026 & 0.735 & ns. \\
\hline Educational status (alternative $3=1$ ) $* * *$ & 0.065 & 0.071 & 0.036 & 0.912 & ns. \\
\hline Educational status (alternative $4=1$ ) $* * *$ & 0.215 & 0.075 & 0.124 & 2.877 & 0.004 \\
\hline Maternal age & -0.021 & 0.005 & -0.116 & -3.900 & $<0.001$ \\
\hline
\end{tabular}




\begin{tabular}{|c|c|c|c|c|c|}
\hline Number of pregnancy (first=1) & 0.102 & 0.048 & 0.060 & 2.116 & 0.035 \\
\hline Gestational age (> 32 weeks $=1$ ) & 0.147 & 0.061 & 0.064 & 2.385 & 0.017 \\
\hline Maternal income (>3000ú=1) & 0.080 & 0.113 & 0.020 & 0.706 & ns. \\
\hline Maternal income (2000-3000ú=1) & 0.086 & 0.059 & 0.043 & 1.452 & ns \\
\hline \multicolumn{6}{|c|}{ Model 3. Positive expectations of a babyô regularity } \\
\hline Adverse life events & 0.040 & 0.021 & 0.053 & 1.875 & 0.061 \\
\hline Depressiveness & -0.038 & 0.009 & -0.177 & -4.194 & $<0.001$ \\
\hline STAI-Anxiety & 0.007 & 0.013 & 0.020 & 0.487 & ns. \\
\hline Stress & 0.004 & 0.011 & 0.016 & 0.391 & ns. \\
\hline Family atmosphere & 0.004 & 0.005 & 0.031 & 0.900 & ns. \\
\hline Closeness* & 0.027 & 0.043 & 0.021 & 0.623 & ns. \\
\hline Dependence (i.e. confidence) & -0.026 & 0.037 & -0.026 & -0.698 & ns. \\
\hline AAS-Anxiety** & 0.057 & 0.040 & 0.052 & 1.398 & ns. \\
\hline Educational status (alternative $2=1$ ) $* * *$ & -0.094 & 0.071 & -0.048 & -1.318 & ns. \\
\hline Educational status (alternative $3=1$ ) $* * *$ & -0.096 & 0.066 & -0.058 & -1.338 & ns. \\
\hline Educational status (alternative $4=1$ ) $* * *$ & -0.154 & 0.069 & -0.098 & -2.228 & 0.026 \\
\hline Maternal age & 0.003 & 0.005 & 0.018 & 0.602 & ns. \\
\hline Number of pregnancy $($ first $=1$ ) & 0.077 & 0.045 & 0.050 & 1.738 & 0.082 \\
\hline Gestational age $(>32$ weeks $=1$ ) & -0.027 & 0.057 & -0.013 & -0.483 & ns. \\
\hline Maternal income ( > 3000ú=1) & 0.089 & 0.105 & 0.025 & 0.847 & ns. \\
\hline Maternal income (2000-3000ú=1) & 0.015 & 0.055 & 0.009 & 0.281 & ns. \\
\hline \multicolumn{6}{|c|}{ Model 4. Absence of expectations of the baby } \\
\hline Adverse life events & 0.019 & 0.056 & 0.009 & 0.335 & ns. \\
\hline Depressiveness & -0.027 & 0.025 & -0.046 & -1.097 & ns. \\
\hline STAI-Anxiety & 0.015 & 0.037 & 0.017 & 0.399 & ns. \\
\hline Stress & 0.030 & 0.030 & 0.041 & 0.990 & ns. \\
\hline Family atmosphere & -0.020 & 0.013 & -0.051 & -1.507 & ns. \\
\hline Closeness* & -0.322 & 0.118 & -0.092 & -2.736 & 0.006 \\
\hline Dependence (i.e. confidence) & -0.148 & 0.100 & -0.056 & -1.480 & ns. \\
\hline AAS-Anxiety** & -0.151 & 0.111 & -0.050 & -1.365 & ns. \\
\hline Educational status (alternative $2=1$ ) $* * *$ & -0.013 & 0.195 & -0.002 & -0.067 & ns. \\
\hline Educational status (alternative $3=1$ ) $* * *$ & 0.033 & 0.182 & 0.007 & 0.184 & ns. \\
\hline Educational status (alternative $4=1$ ) $* * *$ & 0.191 & 0.190 & 0.044 & 1.006 & ns. \\
\hline Maternal age & -0.029 & 0.014 & -0.065 & -2.126 & 0.034 \\
\hline
\end{tabular}




\begin{tabular}{lccccc}
\hline Number of pregnancy (first=1) & 0.254 & 0.122 & 0.060 & 2.079 & 0.038 \\
Gestational age (> 32 weeks =1) & 0.431 & 0.156 & 0.076 & 2.768 & 0.006 \\
Maternal income (>3000ú=1) & 0.048 & 0.289 & 0.005 & 0.165 & ns. \\
Maternal income (2000-3000ú =1) & 0.179 & 0.150 & 0.036 & 1.197 & ns.
\end{tabular}

Closeness*: with excluded item ñI am comfortable having others depend on meò.

Anxiety**: with excluded item ñI want to merge completely with another personò.

Educational status***

Alternative 2: Comprehensive school + vocational education at an upper secondary level or degree from a university of applied sciences or high-school diploma + vocational education at a lower secondary level (Alternative $2=1$ in dummy variable)

Alternative 3: High-school diploma + vocational education at an upper secondary level or degree from a university of applied sciences.

Alternative 4: Comprehensive school or High-school diploma + graduated from a science university.

Control group: Comprehensive school + vocational education at a lower secondary level (maximum)

$\mathrm{B}=$ unstandardized beta

$\mathrm{SE} B=$ standard error

$\mathrm{b}=$ standardized beta

Model 1. $\mathrm{R}^{2}=0.096, \mathrm{R}=0.327$, ANOVA F-ratio =9.697 (pÒ).001); Model 2. $\mathrm{R}^{2}=0.066, \mathrm{R}=0.279$, ANOVA F-ratio $=6.834$ (pÒ).001); Model 3. $\mathrm{R}^{2}=0.020, \mathrm{R}=0.179$, ANOVA F-ratio =2.679 (pÒ.001); Model 4. $\mathrm{R}^{2}=0.024, \mathrm{R}=0.189$, ANOVA F-ratio $=3.027$ (pOO.001). F-value indicates that the model fits the data overall (Field 2013, 342).

Acknowledgements. We would like to thank all the families that participated in the CHILD-SLEEP birth cohort. We are also grateful to the nurses at the maternity clinics who introduced the study to the families. The project was funded by the Academy of Finland (\# 134880 and 253346 TP; \#250480 AK), Gyllenberg Foundation (TP), Yrjö Jahnson Foundation, Foundation for Pediatric Research, Finnish Cultural Foundation, the Competitive Research Financing of the Expert Responsibility area of Tampere University Hospital, Arvo ja Lea Ylppö Foundation, DoctorsôAssociation in Tampere. 